«Keruen» scientific journal

M. O.Auezov Institute of Literature and Art

ISSN 2078-8134

Volume 2, Number 71 (2021)

https://doi.org/10.53871/2078-8134.2021.2-07

IRSTI 17.07

\author{
Kabdeshova K. A. \\ 3rd year $\mathrm{PhD}$ student of the \\ M.O. Auezov Institute of Literature and Art, \\ al-Farabi Kazakh National University, \\ Almaty, Kazakshtan. \\ e-mail: kuralay.kabdeshova@gmail.com
}

\title{
THE EDUCATIONAL ESSENCE OF THE AUTHOR'S HISTORICAL EPICS
}

Summary. To leave rough education and useful teaching for future generations is a burden for adults. In this article, the researcher touches on the idea of the younger generation to become a patriot, linking pedagogy with copyrighted historical epics that are not publicly known. This study considers the issues of forming in younger generations through an author historical epics of qualities such as perseverance, patriotism, love of Motherland, being a hard working person, respect for the elderly, asking for a blessing from the elderly when going on a journey, protecting their people and land, performing civil duty, and etc. To reveal the topic, the author cites samples from the epics of the Zhetysu authors. In particular, patriotic education is linked with the historical epics "Er Azhibay" by Abzeit Malikeuly, "Bayseit Batyr" by Sayadil Kerimbekuly, "Shayan Batyr" by Esdaulet Kandekov. And also the author's views on patriotic education in the article correspond to the messages, programs, and initiatives of the Lider of the country $\mathrm{N}$. Nazarbayev.

Key words: an author historical epic, heroism, faithful service, responsibility, patriotism, discretion, loyalty to friend, dignity, upbringing

Introduction. The Kazakh people who has a good saying "The education begins from the cradle" paid special attention to the upbringing of the offspring. In the upbringing, beliefs, rituals, prohibitions, proverbs, sayings, tales, heroic epics, historical epics, etc. play a huge role.

The Kazakh people used to memorize heroic epics, sung them day and night, and praised the heroic deeds of Kazakh heroes. The generation who heard the heroic epics was inspired by heroes who found favor in the eyes of people. They loved their country, their land, protected it, served faithfully to their country, and fulfilled their responsibilities before the Motherland.

At present, instilling patriotism in younger generation is especially important across the country. The program "Cultural heritage" by the President, the program "The native land" in his article "Orientation to the future: Spiritual Revival", the initiative "Know your land" in the Presidential address "The growth of welfare of the People of Kazakhstan: improving the income and the standard of living (The official site of the president of the republic of Kazakhstan. 2017. URL: $\quad$ http://www.akorda.kz/en/events/akorda_news/press_conferences/course-towardsthefuture-modernization-of-kazakhstans-identity" focus on strengthening patriotic education for the younger generation. At this point, we are not mistaken if we look for the source of patriotic education in the authorial historical epics. 
Since the independence of Kazakhstan, the Kazakh people have been forbidden in the Soviet era and have not been studied for a long time and have been unpublished, and many valuable literary and cultural exhibits of the readership and the scientific community have been released. One of them is historical epics. Independence of the country has also been instrumental in the study of the idea of national liberation which has been widely reflected in historical traditions. It is well-known that any model of historical poetry is dedicated to independence and promotes the heroic deeds and deeds of men who have worn out for the country. That's why the censorship of the Soviet Union has strict control over the correspondence of the centuries-old spiritual heritage of the Kazakh people to the principles of communist ideology and has reached the peak of prohibition. Folk poets from Zhetysu created and sang historical epics. The heroic epos is a great ideological and aesthetic idea - the truthfulness of life and the extraordinary heroic feat of giant battles and hyperbolic exclusively in hyperbolic ways. Well, what's historical epic? 'Historical epics are a part of the Kazakh folklore, which has been a model to showcase the country and sovereignty with an incredible spirit, from generation to generation. It is well-known that the study of the idea of national liberation, which was widely depicted in them, was limited in the Soviet era' (Albekov et al., 2017). The ultimate meaning of the terms 'historical al song', 'historical al poem', 'authorial historical al poem' are similar, their main plot are the difficult times of the people, political news and significant historical events in the country. However, as most literary critics have not explained the distinctions of these terms, their relationships, characteristics and functions are scientifically unclear. 'The birth and evolution of the literature of every nation is a very complex phenomenon. The magic word system that deeply touches the soul of every Kazakh, which has not stayed intact as the time goes, was passed down from father to son orally. The heroic Kazakh sons and daughters, who had a great responsible for their fate, demonstrated the art, as well as the great example of courage. One of the most extensive heritage of the past that has reached this days by word-of-mouth is the historical epics, and the key words in them is the real social and political events' (Rakhim, 1999).

The Russian scientist B.N. Putilov in his composition 'The Russian Historical Folklore of the XIII-XVI Centuries' suggests: 'The specific historical character of the genre is not at all in that the poems reflect in the form of concrete historical plots, the real political conflicts characteristic of this historical moment and for some reason important for the people. The specific historical character resides in the topic of these poems, and their heroes act as the protagonists of the story regardless of whether they were such or not' (Putilov, 1960). Even though the whole truth of life was not reflected in the historical poem, the poet described in it the truth of the time and the main historical event that he saw or heard himself. The heroes that showed their heroism and therefore stayed in the memory of the people were the main character of the historic epics.

Academician M.O. Auezov suggests: 'All these epics, those that were made earlier and later, were based on real historical events and the main characters were real people. Authors of these epics are mostly those who have seen these events. The authors tell stories that they have seen and experienced in the past. Historical epics are different from heroic epos. That is, in the historical epics, the subjective evaluation of the author that takes the events personally replaces the objective narrative characteristic to the epos' (Auezov, 1962). Consequently, the authors transform the facts, events, and historical circumstances that do not come from memory into an expressive poem without much change. Even if they do not know the details of the events, they may be generally familiar with the subject and have interest in it. Therefore, it is enough to draw on the general event and to describe the main hero's image, personality.

The epic tradition is characterized by the fact that one person has been imprisoned and his ordinary character is elevated to a heroic degree. These epic standards are formed over many years. That is why all the epos can be described as broadly as possible, monumental and with great conclusions. 
It is a bit different from the ideological and aesthetic aspect of the historical genius: here special facts of the great event, ordinary people, who are strangled with their courage, heart and mind, from the general public. But they, both personal and fact, are not separated from the general historical situation. Even the entire content of the historical pearl is born and flourished through the events of that time.

Among them there are epics that tell about the Zhungar invasion of the XVII-XX centuries and the People's Movement against enemies and the heroism of the leaders such as Suanbai Aronuly's "Suranshy Batyr", "Sauryk Batyr", Zhambyl Zhabayuly's "Otegen Batyr", Yesdaulet Kandekuly's "Zhetygen batyr", "Shayan Batyr", Abzeit Malikeuly's "Er Azhibai", "Ali Batyr" by Kenen Azerbaiuly, "Partizan Shaimerden", "Musabek Sengirbaev" by Kalka Zhapsarbaiuly, "Bygones" by Koudek Maralbaiuly, "Five guns" by Sayedul Kerimbekuly, Kabylbek Sauranbaiuly's “Karkara uprising”, etc.

Method. One can set an example of many good qualities such as patriotism, heroism, perseverance, responsibility, loyalty to oath, respect for the elderly, respect for the young, leadership, etc. from the heroic epic, historical epics.

One of the heroes who had the above qualities was Azhibai Batyr. The poet Abzeyit (Abdolzeyit) Malikeuly's epic "Er Azhibai" tells about Azhibai Batyr who lived in Zhetysu district and its main theme is a nationwide liberation struggle against the Zhungars' invasion of XVIII century.

From the Alban tribe comes Azhibai batyr, He has won everyone that he fought with.

He has fought with the Kalmyk for a lifetime,

Finally, he drove them out of Alatau (Babalar sozi, 2010).

The main hero of the work Azhibai Naymanbaiuly lived from 1699 to 1778 . He was the same age as Otengen Batyr. The epic "Er Azhibai" tells of such noble qualities as heroism, reasonableness, loyalty to friend, dignity.

The genius people say that,

He is powerful, has a strong body, and smart.

After his forecasting things skillfully, People

called the Otegen Batyr saint.

Otegen was a companion to Azhibai, The

Kalmyks was gone mad seeing this.

Throughout their lives these two used to hit the Kalmyks,

Each time they would take their livestock away (Babalar sozi, 2010).

The epic describes Azhibai in his youth when he protected the Kazakh land from the Kalmyks and took revenge. Despite the age of a hero, he puts himself in danger and considers resisting the enemy his civil duty.

For quite some time it was,

That the Kazakhs and Kalmyks were in conflict.

There came a message to Azhibai that said, "The

Kazakhs were attacked by Kalmyks".

Azhibai could not tolerate this. 
He had not seen this humiliation before.

"I'm going to take vengeance on Kalmyk"

That was his message to the people (Babalar sozi, 2010).

One of the epics that describe the desire for independence and praises heroism is the "Baiseit Batyr" epic. The epic "Baiseit Batyr" was sung by the Zhetysu folk poet Sayadil Kerimbekov. It tells about Baiseyit Batyr's heroism shown in regulating the cold-blooded relations between the Kazakh and Kyrgyz people, bringing peace to both countries.

There are epics and stories about Bayseyit Toyshibekuly who was well-known in history. Bayseit's grandfather, Saman, his father, Toyshibek, were also batyrs (heroes). Baiseit Batyr was the youngest member of the rebel army led by Kenesary Kassymov. He stood out with his heroism and enjoyed the attention of the people. The poet Sayadil Kerimbekov wrote a epic based on the folk epics praising his heroism.

\author{
Baiseit hero \\ Attacked the enemy. \\ His horse was sweating a lot. \\ Many people Died \\ of his arrow. The \\ noise of guns \\ Went down. \\ Everyone felt burning in their flesh. \\ Many were injured, \\ Their blood splashed like water. \\ Baiseit was above his strength, \\ So he kicked out the enemy (Babalar sozi, 2010).
}

In the battlefield of heroism, Bayseyit batyr defeated the enemy with a mastery of the hero and kicked them out of the border. At this point it is necessary to note the batyr's shooting skills. Poet Sayadil Kerimbekov describes the heroism of the hero as in heroic epics, and honors courage and heroism setting it an example for the future generations.

When the hard times came for his people Baiseit Batyr immediately stormed the enemy and lived up to hope of his people.

You were like a lion, Baiseit,

But you suddenly fell from your horse. Who

will now stop the enemy?

The day has come to the people

When it lost its hero

It is a sad day (Babalar sozi, 2010).

Apart from Baiseit in this epic, Sypatai, Agybai, Syzdyk batyr were killed by the enemy.

Another epic about patriotism is "Shayan Batyr" by Yesdaulet Kandekov. E.Kandekov's epic "Shayan Batyr" is one of the less studied, unpublished, and unpopular epics. It is significant in instilling love for the Homeland, teaching heroism to future generations. In the future it is necessary to study the epic. As we can see, at some point the events and activities in the epic are incompatible with historical and political events in real life. However, the author could reveal the image of Shayan batyr. I am convinced that the epic "Shayan Batyr" where the heroism of a hero 
in the fight with the enemy for freedom is praised, will attract attention of the literary scholars in the future (Kabdeshova and Harris, 2018).

At the age of ten, he was riding a camel and cut the head of Kalmyk with an axe. In order to prevent the Kalmyk people to take revenge on the country Baba Kara was forced to hide in the Black Cave.

At the age of sixteen, he heard that his relative Sat batyr was killed by the Kyrgyz.

"Hey, there, I have anger, I

am sixteen,

My brother Sat has died, I

am on the race.

Uman killed the Sat batyr,

He brought trouble to the country, If

you, my people, approve of that, I'm

craving for his blood.

If I do not take the revenge,

Why am I born a hero? (Kandekov, 1940).

Thus, Shayan batyr feeling responsibility for protecting the country confronts the opponent, and even fights the dragon.

In heroic epics, historical epic there is a motive of asking for permission from the elderly. Before a serious war, the heroes took the permission of the elderly, as well as their blessing.

- Kerim Batyr, Kuat Batyr,

You have seen a lot in life,

I ask you one thing,

... Unless I do a great thing, My

heart is in grief.

If you allow, big brothers,

I want to go to Kalmyk (Kandekov, 1940).

In such fierce battles, the hero stood out by his leadership qualities. He was able to organize the process of preparation to war such as soldier training, tool making, choosing a way of fighting, defining pathway, etc.

The scenes in the heroic epics like Kobylandy batyr's herding horses, Kambar batyr's hunting, and Targyn's training a horse can be found in historical epics. The horses of heroes that became their companions complement their heroism.

In the epic "Shayan Batyr":

Black cave was lower than Auliatah. Baba lived there for six years. While in the cave, the offspring of Syrymbet baba fell short. A red mare becomes pregnant, gives birth, then many people were fed by its milk. There is edification since then "Baba milked the cattle, Syrymbet ate dry bread". He gifts the red foal of that mare to Shayan. That red foal becomes a five old horse. Shayan besomes sixteen years old. This red horse becomes known as Shayan's red horse and the best companion to Shayan.

In the epic "Er Azhibai":

Azhibai rode the Kulagabel himself $\mathrm{He}$

rode the horse at night.

He screamed "Azhibai" while riding

He made lots of noise in the village (Babalar sozi, 2010).

In his article titled "Seven Wonders of the Great Steppe", the President pays special attention to the culture of horse riding, horse training mentioning that: "The image of a warrior 
with a flag is the most famous emblem of the era of heroes, as well as the distinctive element of the "cultural code" of nomadic world formed by the emergence of the cavalry" (The official site of the president of the republic of

Kazakhstan.2018.URL:http://www.akorda.kz/kz/addresses/addresses_of_president/memleketbas shysy-nanazarbaevtyn-kazakstan-halkyna-zholdauy-2018-zhylgy-5-kazan). It is certain that the younger generation can be educated on the importance of labor through the various examples in the historical epics ("Kenkyzyl" of Shayan batyr, "Kulatobel" of Azhibai batyr) such as recognizing the value of horses and looking after them as they used to play a big role in the life of nomad people.

Results. In times of war, the unity of the country and the heroism of a man came under criticism. Men preferred to die in the hands of the enemy rather than waiting for death, and they considered it to be honorable. In today's civilized, peaceful time men are eager to refuse to fulfill their civic duty before their homeland. Taking this into account, the government is organizing various programs and events across the country to educate young people about patriotism, and encourage men to fulfill their civic duty. The President in his Address on October 5, 2018 emphasizes the need to improve the patriotic education: "It is necessary to strengthen the role of military-patriotic education in schools, creating a youth association "Sarbaz" such as the Boy Scout Movement" (The official site of the president of the republic of Kazakhstan. 2018. URL: http://www.akorda.kz/kz/addresses/addresses_of_president/memleket-basshysynanazarbaevtynkazakstan-halkyna-zholdauy-2018-zhylgy-5-kazan).

Conclusion. A citizen who loves and is proud of his homeland contributes to its improvement. At the moment, there is a focus on educational activities on personality development, self-development, and self-employment. Measures are being taken to strengthen patriotism, to love the homeland, to be persistent, hardworking in the times of globalization. For this purpose, the role of historical epics is unique. The historical epos does not choose either age or gender. Everyone can take useful things from historical epics and become a person.

\author{
Қабдешова К.А. \\ әл-Фараби атындағы Қазақ ұлттық университеті, \\ М.О. Әуезов атындағы Әдебиет және өнер \\ институтының 3-курс докторанты, \\ Алматы, Қазақстан. \\ e-mail: kuralay.kabdeshova@gmail.com
}

\title{
АВТОРЛЫК ТАРИХИ ЖЫРЛАРДЫН ТӘРБИЕЛІК МӘНІ
}

Түйін. Келер ұрпаққа тәлімді тәрбие мен пайдалы ілім қалдыру ересектердің мойнындағы жүк болып табылады. Мақалада авторлық тарихи жырлар арқылы жас ұрпақты қайсарлыққа, ұлтжандылыққа, Отанын сүю, еңбекқор болу, үлкенді сыйлау, жол жүргенде үлкендерден бата алу, елін, жерін қорғауға, азаматтық борышты өтеуге т.с. қасиеттерді жас жеткіншектердің бойына қалыптастыру мәселелері қарастырылады. Зерттеуші ұсынылып отырған мақалада өскелең ұрпақтың ұлтжанды болып өсу идеясын қозғай отырып, көпшілікке таныс емес авторлық тарихи жырларды педагогикамен байланыстырады. Тақырыпты ашу үшін автор Жетісу авторларының жырларынан мысалдар келтіреді. Атап айтқанда, патриоттық тәрбиені Әбзейіт Мәлікеұлының «Ер Әжібай», Саяділ Керімбекұлының «Байсейіт батыр», Есдәулет Қандековтың «Шаян батыр» жырларымен сабақтастырады. Сондай-ақ автордың мақалада алға тартып отырған патриоттық тәрбие туралы пікірлері елбасы Н.Назарбаевтың халыққа жолдаған жолдауларымен, бағдарламаларымен, бастамаларымен үндесіп келеді. 
Кілт сөздер:авторлық тарихи жыр, батырлық, адал қызмет ету, жауапкершілік, патриот болу, парасаттылық, досқа адалдық, намысқойлық, тәрбие.

Кабдешова К.А. Докторант 3-курса

Института литературы и исскуства им.

М.О.Ауэзова,

Казахский национальный

университет им. аль-Фараби,

Алматы, Казахстан.

e-mail: kuralay.kabdeshova@gmail.com

\section{ВОСПИТАТЕЛЬНАЯ СУЩНОСТЬ АВТОРСКИХ ИСТОРИЧЕСКИХ ЭПОСОВ}

Резюме. Оставить примерное воспитание и полезное учение для будущих поколений это бремя для взрослых. В предлагаемой статье исследователь затрагивает идею подрастающего поколения стать патриотом, связывая педагогику с авторскими историческими эпосами, которые публично не известны. В данном исследовании рассматриваются вопросы формирования молодого поколения с помощью авторские исторические эпосы таких качеств, как настойчивость, патриотизм, любовь к Родине, трудолюбивый человек, уважение к пожилым, просьба о благословении от пожилых людей в поездке. защита своих людей и земли, выполнение гражданских обязанностей и т. д. Чтобы раскрыть тему, автор приводит образцы из эпосов Жетысуских авторов. В частности, патриотическое воспитание увязывается с историческими эпосами «Ер Ажибай» Абзеита Маликеулы, «Байсеит батыр» Саядиля Керимбекулы, «Шаян батыр» Есдаулета Кандекова. А также взгляды автора на патриотическое воспитание в статье соответствуют сообщениям, программам, инициативам Елбасы страны Н. Назарбаева.

Ключевые слова: авторское историческое сказание, героизм, верное служение, ответственность, патриотизм, благоразумие, верность другу, достоинство, воспитание.

\section{Information about authors:}

Kabdeshova K. A., 3rd year PhD student of the M.O. Auezov Institute of Literature and Art, al-Farabi Kazakh National University, Almaty, Kazakshtan. e-mail: kuralay.kabdeshova@ gmail.com. ORCID iD: 000000024783-5705

\section{REFERENCES}

[1] Article of the President of the Republic of Kazakhstan Nursultan Nazarbayev "Seven Facets of the Great Steppe". (2018). The official site of the president of the republic of Kazakhstan. Retrieved 22.09.2019.

http://www.akorda.kz/kz/addresses/addresses_of_president/memleket-basshysy-nanazarbaevtyn-kazakstan-halkynazholdauy2018-zhylgy-5-kazan (kaz.)

[2] Albekov, T.K., Alpysbayeva, K.B. and Auyesbayeva, P.T. (2017). Distinctive and educational features of Kazakh folklore by the example of "Words of Ancestors". Revista ESPACIOS, 38(45), 33 p. (eng.) http://www.revistaespacios.com/a17v38n45/17384533.html

[3] Rakhym, B.S. (1999). The nature of historical epos: the poetics of Kazakh historical epics. Karaganda: publishing house of KarMU. (kaz.)

[4] Putilov, B.N. (1960). Russian historical song folklore of the XIII-XVI centuries. Moscow - Leningrad: Publishing House of the USSR Academy of Sciences. (rus.)

[5] Auezov, M. (1962). Time and literature. Almaty: Kazakhstan national belles-letters publishing house. (kaz.)

[6] Babalar sozi: 100 volumes. T.63: Historical epics. - Astana: Foliant, 2010. - 456 p. (kaz.)

[7] Babalar sozi: 100 volumes. T.60: Historical epics. - Astana: Foliant, 2010. - 448 p. (kaz.)

[8] Course towards the future: modernization of Kazakhstan's identity. (2017). The official site of the president of the republic of Kazakhstan. Retrieved 22.09.2019. http://www.akorda.kz/en/events/akorda_news/press_conferences/course-towards-thefuturemodernization-of-kazakhstans-identity (kaz.) 
[9] Kabdeshova K.A., Harris O. (2018). E.Kandekov's legend "Shayan batyr": a historic and epic tradition. Eurasian journal of philology: science and education of al-Farabi Kazakh national university, 4, 170-174. (eng.)

[10] Kandekov Y. (1940). Shayan batyr (manuscript). Central Scientific Library of RSE «Gylym [11] Ordasy», 678-pack, 5notebook. (kaz.)

\section{ӘДЕБИЕТ}

[1] Әлбеков, Т.К., Алпысбаева, Қ.Б.. және Әуесбаева, П.Т. (2017). «Бабалар сөзі» мысалындағы қазақ фольклорының өзіндік ағартушылық ерекшеліктері. Revista ESPACIOS, 38(45), 33.

[2] Әуезов, М. (1962). Уақыт және әдебиет. Алматы: Қазмемкөркемәдеббас.

[3] Бабалар сөзі: 100 томдық. Т.60: Тарихи жырлар. - Астана: Фолиант, 2010. - 448 б.

[4] Бабалар сөзі: 100 томдық. Т.63: Тарихи жырлар. - Астана: Фолиант, 2010. - 456 б.

[5] Қабдешова Қ.А., Харрис О. (2018). Е.Қандековтің «Шаян батыр» жыры: тарихилық және эпикалық дәстүр. ӘлФараби атындағы Қазақ ұлттық университеті Хабаршысы. Филология сериясы, 4, 170-174.

[6] Қандеков Е. (1940). Шаян батыр (қолжазба). «Ғылым Ордасы» РМК Орталық ғылыми кітапханасы, 678-бума, 5 дәптер.

[7] Мемлекет басшысының «Болашаққа бағдар: рухани жаңғыру» атты мақаласы. (2017). Қазақстан республикасы президентінің ресми сайты. Қаралған күні: 22.09.2019.

http://www.akorda.kz/en/events/akorda_news/press_conferences/course-towards-the-future-modernization-of-kazakhstansidentity

[8] Мемлекет басшысының «Ұлы даланың жеті қыры» атты мақаласы. (2018). Қазақстан республикасы президентінің ресми сайты. Қаралған күні:22.09.2019.http://www.akorda.kz/kz/addresses/addresses_of_president/memleketbasshysynanazarbaevtyn-kazakstan-halkyna-zholdauy-2018-zhylgy-5-kazan

[9] Путилов, Б.Н. (1960). XIII-XVI ғасырлардағы Ресей тарихи-өлең фольклоры. Мәскеу-Ленинград: КСРО Ғылым академиясы баспасы. [10] Рақым, Б.С. (1999). Тарихи эпос табиғаты: Қазақ тарихи жырларының поэтикасы. Қарағанды: ҚарМУ баспасы.

\section{ЛИТЕРАТУРА}

[1] Албеков, Т.К., Алпысбаева, К.Б.. және Ауесбаева, П.Т. (2017). Отличительные и воспитательные особенности казахского фольклора на примере «Бабалар сози». Revista ESPACIOS, 38(45), 33. http://www.revistaespacios.com/a17v38n45/17384533.html

[2] Ауэзов, М. (1962). Время и литература. Алматы: Каз. гос. изд. худож. лит.

[3] Бабалар сози: 100-томник. Т.60: Исторические поэмы. - Астана: Фолиант, 2010. - 448 с.

[4] Бабалар сози: 100-томник. Т.63: Исторические поэмы. - Астана: Фолиант, 2010. - 456 p.

[5] Кандеков Е. (1940). Шаян батыр (рукопись). Центральная научная библиотека РГП «Ғылым Ордасы», 678-папка, 5тетрадь.

[6] Қабдешова Қ.А., Харрис О. (2018). Сказание Е.Кандекова «Шаян батыр»: историчность и эпическая традиция. Вестник Казахского национального университета. Серия филологическая. 4, 170-174.

[7] Путилов, Б.Н. (1960). Русский историко-песенный фольклор XIII-XVI веков. Москва-Ленинград: Издательство Академии наук СССР.

[8] Ракым, Б.С. (1999). Природа исторических эпосов: Поэтика казахских исторических эпосов. Караганда: Издательский дом КарМУ.

[9] Статья Главы государства «Взгляд в будущее: модернизация общественного сознания». (2017). Официальный сайт

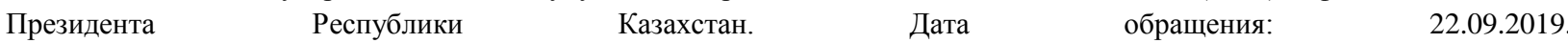
http://www.akorda.kz/en/events/akorda_news/press_conferences/course-towards-the-future-modernization-of-kazakhstansidentity [10]Статья Главы государства «Семь граней Великой степи». (2018). Официальный сайт Президента Республики Казахстан. Дата обращения: 22.09.2019.http://www.akorda.kz/kz/addresses/addresses of president/memleketbasshysynanazarbaevtyn-kazakstan-halkyna-zholdauy-2018-zhylgy-5-kazan 